\title{
ヒト多能性幹細胞由来肝細胞を用いた次世代型創薬の実現を目指した基盤技術創成
}

\author{
高山和雄 $a, b, c$
}

\section{Establishment of a Method of Hepatocyte Differentiation from Human Pluripotent Stem Cells for Innovative Drug Development}

\author{
Kazuo Takayama ${ }^{a, b, c}$ \\ ${ }^{a}$ iPS Cell-based Research Project on Hepatic Toxicity and Metabolism, Graduate School of Pharmaceutical Sciences, \\ Osaka University; 1-6 Yamadaoka, Suita, Osaka 565-0871, Japan: ${ }^{b}$ Laboratory of Biochemistry and Molecular \\ Biology, Graduate School of Pharmaceutical Sciences, Osaka University; 1-6 Yamadaoka, Suita, Osaka 565-0871, \\ Japan: and ${ }^{c}$ Laboratory of Hepatocyte Regulation, National Institutes of Biomedical Innovation, Health and \\ Nutrition; 7-6-8 Saito Asagi, Ibaraki, Osaka 567-0085, Japan.
}

(Received June 7, 2015)

\begin{abstract}
Hepatocyte-like cells differentiated from human pluripotent stem cells (such as human embryonic stem (ES) cells and induced pluripotent stem (iPS) cells) are expected to be utilized in drug screening. However, the hepatocyte differentiation efficiency and hepatic functions of hepatocyte-like cells were not sufficient to perform ES/iPS cell-based drug discovery. Therefore, we decided to improve the method of hepatocyte differentiation from human ES/iPS cells. To enhance this hepatocyte differentiation efficiency, hepatocyte-related transcription factors, such as forkhead box protein A2 (FOXA2) and hepatocyte nuclear factor 1 alpha (HNF1 $\alpha$ ), were overexpressed during the hepatocyte differentiation process. In addition, to enhance the functions of hepatocyte-like cells, these cells were cultured in three dimensional (3D) conditions using a Nanopillar plate. By FOXA2 and HNF1 $\alpha$ overexpression, human ES/iPS cells could efficiently (more than $80 \%$ ) differentiate into albumin-positive hepatocyte-like cells. Various hepatic functions, including albumin secretion and drug metabolism capacities, of the hepatocyte-like cells were significantly enhanced by performing 3D cell culture. These results suggest that the method of hepatocyte differentiation could be improved by using gene transfer and 3D cell culture technologies. We believe that these new hepatocyte-like cells would be useful tools in drug development.
\end{abstract}

Key words — hepatocyte; human embryonic stem cells; human induced pluripotent stem cells; drug metabolism; drug screening

\section{1.はじめに}

肝毒性の判明は薬物の開発中止や市場撤退となる 主要な原因の 1 つである. ${ }^{1)}$ 現在の創薬過程では, 薬物の肝毒性を予測するためにヒト初代培養肝細胞 (primary human hepatocyte; PHH) が汎用されて いるが，PHH はほとんど増殖能を持たず，ロット 差や同一ロットの入手に制限があり, 非常に高価で

\footnotetext{
${ }^{a}$ 大阪大学大学院薬学研究科 iPS 肝毒性・代謝プロジェ クト（干565-0871 大阪府吹田市山田丘 1-6), ${ }^{b}$ 大阪大 学大学院薬学研究科分子生物学分野 (下565-0871 大阪 府吹田市山田丘 1-6), c医薬基盤・健康 - 栄養研究所肝 細胞分化誘導プロジェクト（テ567-0085 大阪府茨木市 彩都あさぎ 7-6-8)

e-mail: takayama@phs.osaka-u.ac.jp

本総説は, 平成 26 年度日本薬学会近畿支部奨励賞（生 物系薬学) の受賞を記念して記述したものである.
}

あるため, 創薬スクリーニングに適したツールであ るとは言い難い。そこで，ほぼ無限増殖可能であ り, 多分化能を有するヒト embryonic stem (ES)/ induced pluripotent stem（iPS）細胞から PHH と同 等の機能を有した肝細胞を効率よく作製できれば, 非常に有用なツールになり得ると期待されている. しかしながら，ヒト ES/iPS 細胞から肝細胞への分 化誘導法にはいくつかの問題点がある. 1 つ目は, 分化誘導効率が十分に高くない，2つ目は，ヒト ES/iPS 細胞由来肝細胞の肝機能が PHH と比べて 劣る, 3 つ目はヒト $\mathrm{ES} / \mathrm{iPS}$ 細胞由来肝細胞の調製 に長い培養時間と高いコストを要する, という問題

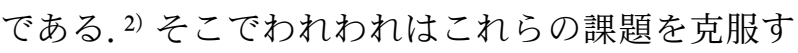
るため, 遺伝子導入技術や三次元培養技術を駆使し て, ヒト ES/iPS 細胞から肝細胞への分化誘導法の 
A

stage

stage II

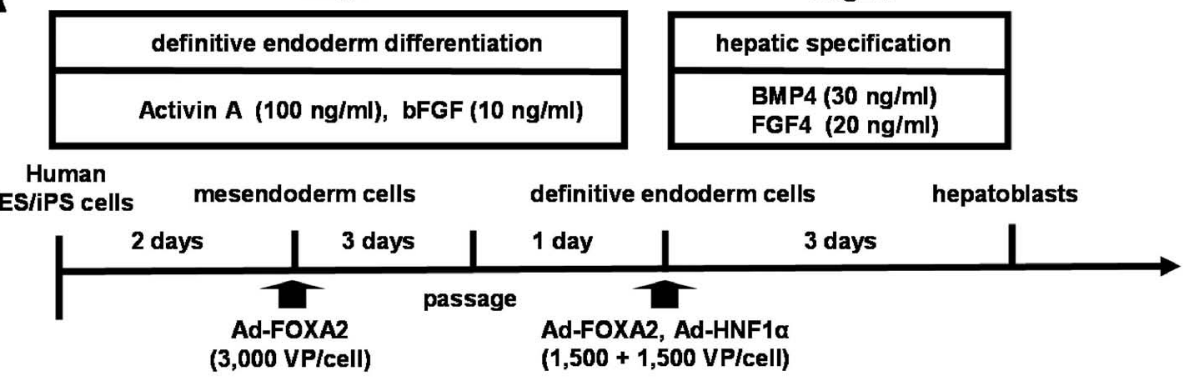

stage III

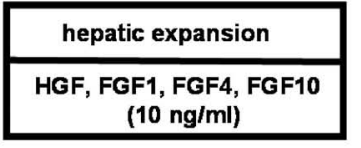

(10 $\mathrm{ng} / \mathrm{ml}$ )

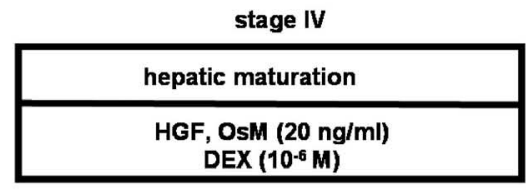

hepatoblasts

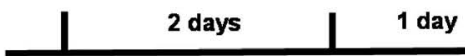

passage

Ad-FOXA2, Ad-HNF1a

$(1,500+1,500$ VP/cell $)$

\section{Ad-FOXA2, Ad-HNF1c}

$(1,500+1,500$ VP/cell $)$

B
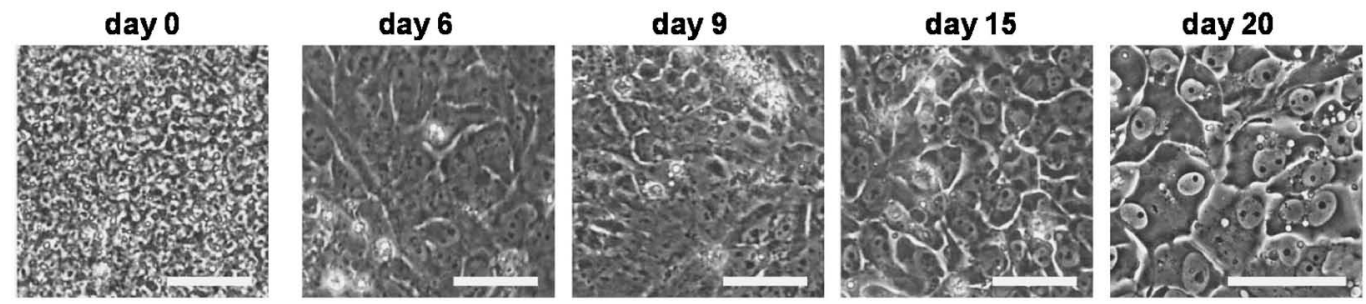

Fig. 1. Highly Efficient Hepatocyte Differentiation of Human ES/iPS Cells by FOXA2 and HNF1 $\alpha$ Transduction $^{8)}$

(A) The procedure for differentiation of human ES/iPS cells into hepatocyte-like cells via definitive endoderm cells and hepatoblasts is presented schematically. (B) Sequential morphological changes (day 0-20) of human ES cells (H9) differentiated into hepatocyte-like cells are shown. The scale bars represent $50 \mu$ m. Reproduced from Ref 8), with permission from Elsevier.

改良に取り組んだ。さらに，肝細胞の前駆細胞であ る肝幹前駆細胞の複製技術を開発することにより, 肝細胞作製に要する培養期間の短縮とコスト削減を 目指した。

2. 遺伝子導入技術を用いた高効率肝細胞分化誘 導法の開発

ヒト ES/iPS 細胞から肝細胞への分化効率を向上 させるため, 本研究では分化途中の細胞に対して, 遺伝子導入効率に特に優れた独自開発のアデノウイ ルス（Ad）ベクター3)を用いて肝関連転写因子を遺

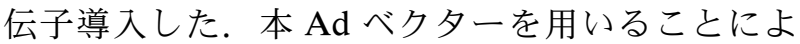
り，あらゆる分化段階の細胞（未分化細胞，中内胚 葉細胞，内胚葉細胞，肝幹前駆細胞）に対して，ほ ぼ $100 \%$ の効率で遺伝子導入可能であった. ${ }^{4-7)}$ 様々 な肝関連転写因子をスクリーニングした結果, forkhead box protein A2 (FOXA2) 及び hepatocyte nuclear factor 1 alpha (HNF1 $\alpha)$ 遺伝子が最も強力
な肝分化促進効果を発揮すること見い出した $[$ Fig. $1(\mathrm{~A})] .{ }^{8)}$ 従来の遺伝子導入を実施しない分化誘導 法（液性因子や化合物のみを用いた分化誘導法）で は albumin (ALB) 陽性細胞への分化効率は約 40 \%であったが，FOXA2 及び HNF1 $\alpha$ 遺伝子を導入 することによって，約 $80 \%$ に向上した．このよう にして作製した肝細胞は，肝細胞特有の明瞭な輪郭 と 2 核を有していた [Fig. 1(B)]．以上のことから， FOXA2 及び HNF1 $\alpha$ 遺伝子を導入することによっ て，ヒト ES/iPS 細胞から肝細胞への分化を促進で きることが示された。

3. 三次元培養技術を用いたヒト ES/iPS 細胞由 来肝細胞の機能向上

ヒト ES/iPS 細胞由来肝細胞の薬物代謝機能を始 めとした各種肝機能を向上させるために，本研究で はヒト ES/iPS 細胞由来肝細胞の三次元培養を行っ た. プレート表面に多数の微細な突起 (ナノピラー) 
A

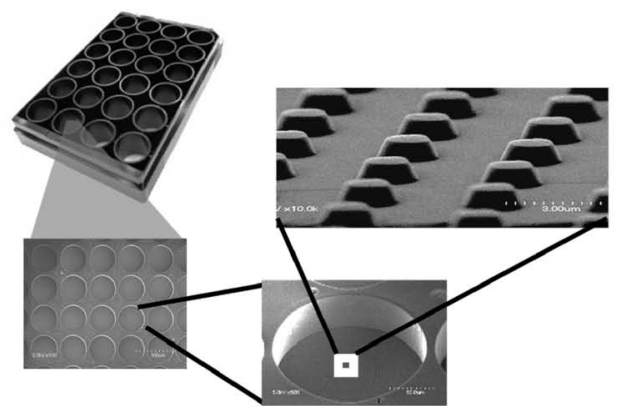

B

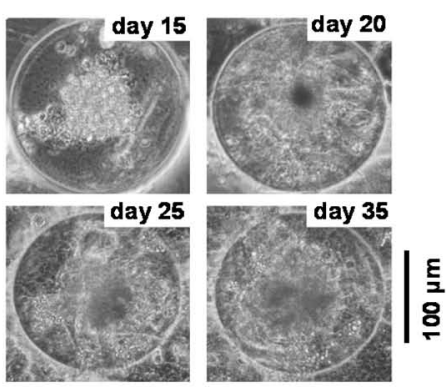

C

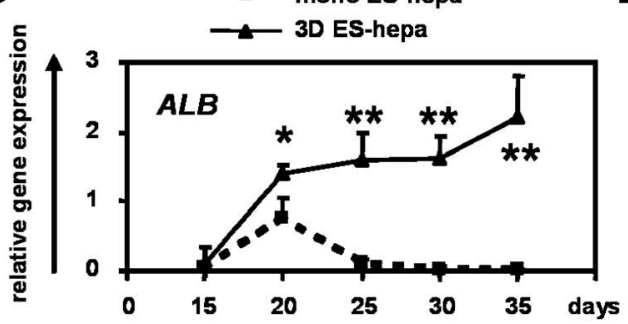

D

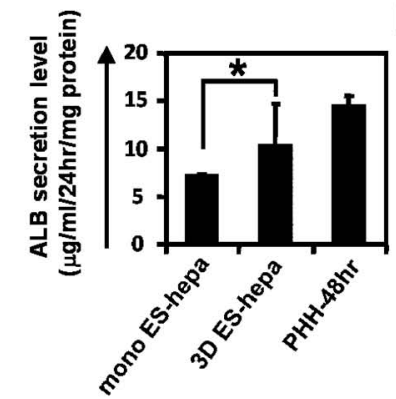

E

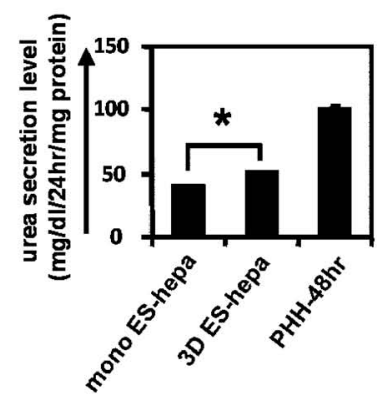

\section{$\mathbf{F}$}
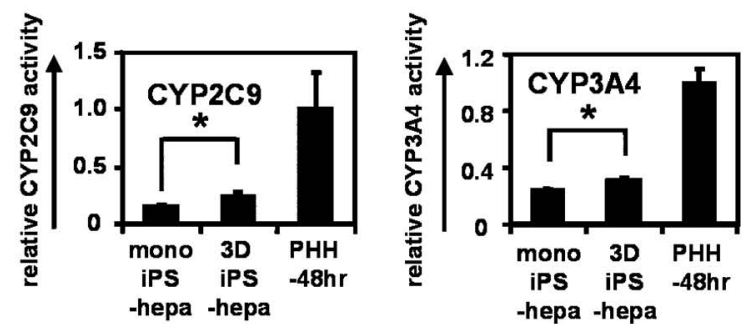

Fig. 2. Hepatocyte Functions in Human ES/iPS-derived Hepatocyte-like Cells Were Enhanced by Using Nanopillar Plate ${ }^{9)}$

(A) Photograph display of a 24-well format Nanopillar Plate and its microstructural appearances of the hole and pillar structure. (B) Phase-contrast micrographs of the hepatocyte-like cell spheroids on the Nanopillar Plate are shown. Scale bar represents $100 \mu \mathrm{m}$. (C) The gene expression levels of $A L B$ were measured by real-time RT-PCR on day 15, 20, 25, 30, and 35. On the y axis, the gene expression levels in PHH (three lots of PHH were used in all studies), which were cultured for $48 \mathrm{~h}$ after plating (PHH-48hr), were taken as 1.0. (D, E) The amount of ALB (D) and urea (E) secretion were examined in the mono ES-hepa (monolayer cultured hepatocyte-like cells; day 20), the 3D ES-hepa (3D cultured hepatocyte-like cells; day 35), and PHH-48hr. (F) The CYP activity was measured in the mono iPS-hepa (day 20), the 3D iPS-hepa (day 35), and PHH-48hr. On the y axis, the CYP activity in PHH-48hr was taken as $1.0 .{ }^{*} p<0.05$; ${ }^{* *} p<0.01$. Reproduced from Ref 9), with permission from Elsevier.

を有したナノピラープレートを用いることによって [Fig. 2(A) ], ナノピラー上にスフェロイド（細胞 凝集塊）を形成させることができた [Fig. 2(B)]. スフェロイドの直径は約 $100 \mu \mathrm{m}$ であり，細胞中心 部が低酸素・低栄養にならない程度のスフェロイド 径であると考えられる。ナノピラープレートを用い ることにより，ヒト $\mathrm{ES}$ 細胞由来肝細胞の肝機能が 向上するかどうか確かめるために，まず $A L B$ 遺伝 子発現量を real-time RT-PCR 法により解析した. 三次元培養することにより, $A L B$ 遺伝子発現量は 二次元培養時よりも有意に高く，その発現レベルは 長期間（分化誘導 35 日目まで）に渡って維持され ていた [Fig. 2(C)]. また, ALB [Fig. 2(D)] ・尿 素産生能 [Fig. 2(E)] についても検討したところ, いずれも三次元培養したヒト ES 細胞由来肝細胞の
方が有意に高く, PHH の産生量の $50 \%$ 以上であっ た。さらに，薬物代謝酵素 CYP2C9, CYP3A4 の活 性を測定したところ，いずれも三次元培養したヒト iPS 細胞由来肝細胞の方が有意に高かった [Fig. 2 (F) ]. 以上のことから，ヒト ES/iPS 細胞由来肝細 胞の薬物代謝機能を始めとした各種肝機能はナノピ ラープレートを用いて三次元培養することにより向 上可能であることが示唆された. ${ }^{9}$

4. 創薬応用を見据えたヒト ES/iPS 細胞由来肝 細胞の大量供給システムの構築

ヒト ES/iPS 細胞由来肝細胞を用いた創薬を実現 するためには，細胞を迅速かつ大量に供給できるシ ステムを構築することが必須である。しかしなが ら，ヒト ES/iPS 細胞から肝細胞への分化誘導期間 は長く, 分化誘導に要するコストは非常に高い（特 
A

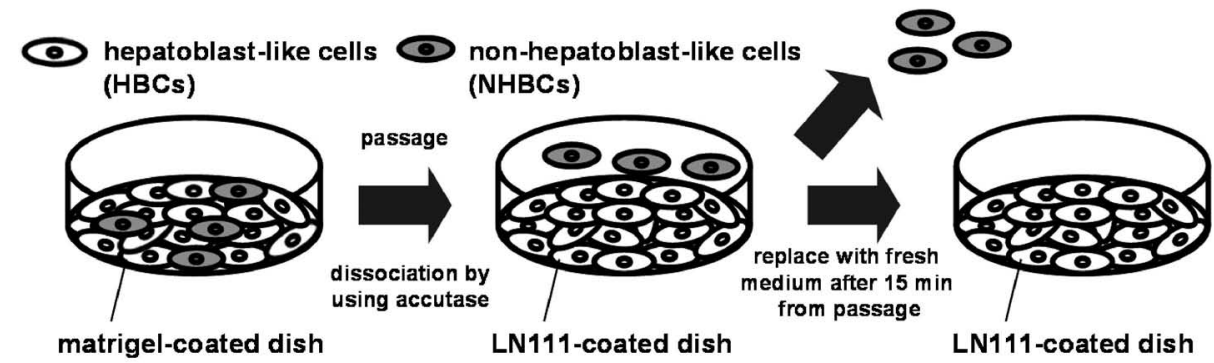

B

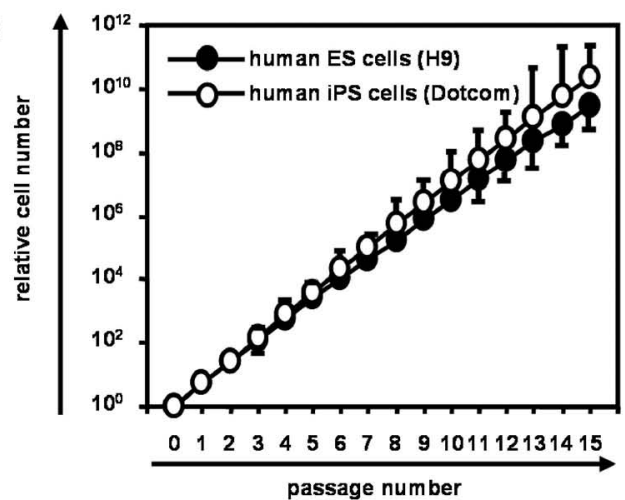

D

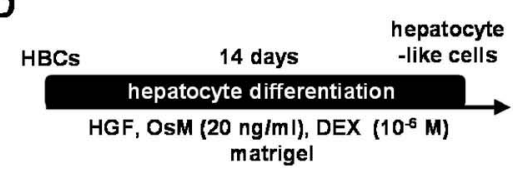

E

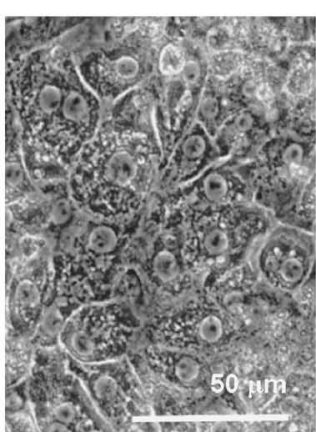

$\mathbf{F}$
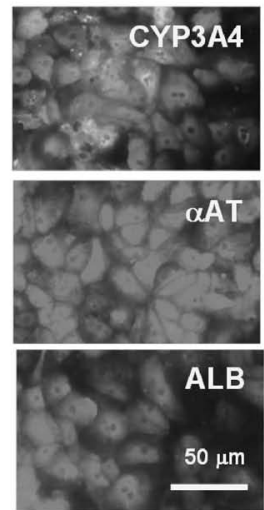

C

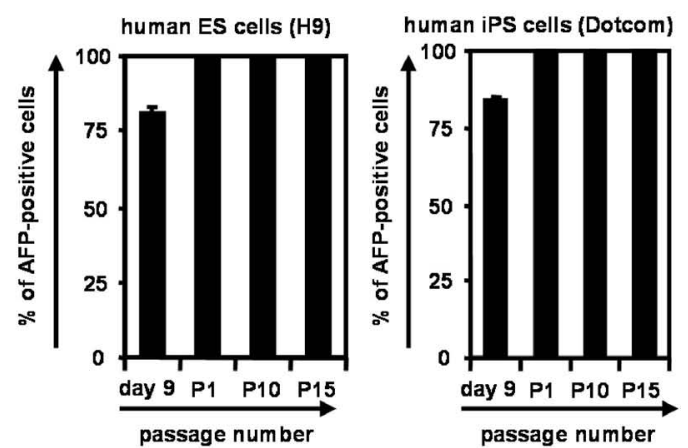

G
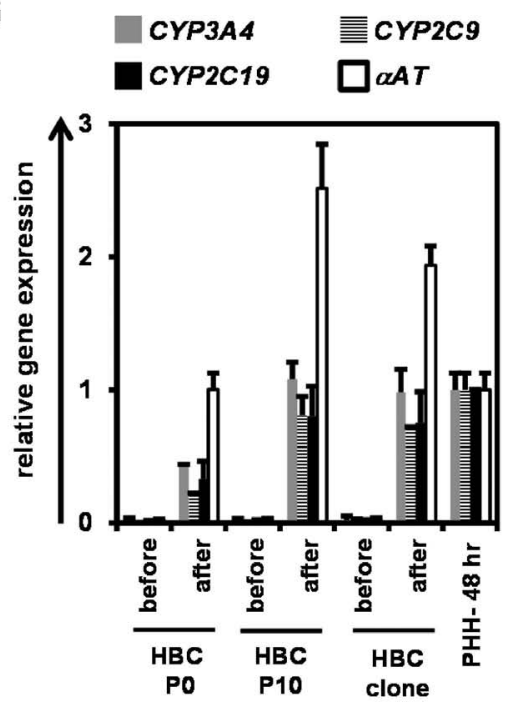

Fig. 3. The Human ES/iPS-derived Hepatoblast-like Cells Could Self-replicate on a Human LN111-coated Dish, and Differentiate into the Hepatocyte-like Cells ${ }^{10}$

(A) The human ES/iPS cell-derived cells (day 9) were plated onto a human LN111-coated dish. At 15 min after plating, the unattached cells were removed. (B) The hepatoblast-like cell derived from human ES cells (H9) or human iPS cells (Dotcom) were cultured and cell growth was analyzed by obtaining a cell count at each passage. Data represent the mean \pm S.D. from three independent experiments. (C) The percentage of AFP-positive cells was examined by using FACS analysis on day 9 (before passage), P1 (HBCs passaged once), P10 (HBCs passaged 10 times), and P15 (HBCs passaged 15 times). Data represent the mean \pm S.D. from seven independent experiments. (D) The procedure for differentiation of the human ES cell (H9) -derived HBC P0, HBC P10, or HBC clone into the hepatocyte-like cells is presented schematically. (E) Phase-contrast micrographs of the HBC P10-derived hepatocyte-like cells are shown. (F) The HBC P10-derived hepatocyte-like cells were subjected to immunostaining with anti-CYP3A4, $\alpha$ AT, or ALB antibodies. (G) The gene expression levels of hepatocyte markers in HBC P0-, HBC P10-, or HBC clone-derived hepatocyte-like cells were measured by real-time RT-PCR after 14 d of hepatocyte differentiation. The gene expression levels in primary human hepatocytes (three lots of cryopreserved human hepatocytes were used), that were cultured for $48 \mathrm{~h}$ after the cells were plated (PHH-48hr), were taken as 1.0. Data represent the mean \pm S.D. from three independent experiments. Student's $t$ test indicated that gene expression levels of the hepatocyte markers in "after" were significantly higher than those in "before" $(p<0.01)$. Reproduced from Ref 10$)$, with permission from Elsevier.

にヒト $\mathrm{ES} / \mathrm{iPS}$ 細胞から内胚葉細胞へのステップが 高額な試薬を要する）ことが知られている。そこ で，ヒト ES/iPS 細胞由来肝細胞の前駆細胞である 肝幹前駆細胞における複製技術が開発できれば，こ
れらの問題が解決できると考えた。 まず，ヒト ES/ iPS 細胞由来肝幹前駆細胞（hepatoblast-like cells; $\mathrm{HBC}$ ）の複製に適した細胞外基質の探索を実施し たところ， laminin 111 が最も適した細胞外基質で 
あることを発見した. ${ }^{10)}$ Laminin 111 を用いた HBC の培養法の模式図を Fig. 3 (A) に示す。Laminin 111 を用いて HBC を培養することにより，15 回に 渡り継代可能であり, 細胞数にして $10^{10}$ 倍程度ま で増殖可能であった [Fig. 3(B)]。 また，その間， 肝幹前駆細胞マーカーである alpha fetoprotein (AFP) の陽性率はほぼ $100 \%$ のま維持されてい た [Fig. 3(C)]. 以上の結果から, laminin 111 を 用いて $\mathrm{HBC}$ を維持・増殖可能であることが示され た。次に, laminin 111 上で増殖させた HBC が肝 細胞への分化能を有するかどうか評価した．Figure 3(D) のプロトコールにしたがって，HBC を肝細胞 へと分化誘導したところ，肝細胞特有の形状を有し た細胞を作製できた [Fig. 3(E)]。また，HBCか ら作製した肝細胞は CYP3A4, alpha-1-antitrypsin $(\alpha \mathrm{AT}), \mathrm{ALB}$ といった各種肝マーカーを強く発現 していることが免疫染色法により確認された［Fig． $3(\mathrm{~F})$ ）。さらに, 肝分化前の $\mathrm{HBC}$ と $\mathrm{HBC}$ 由来肝 細胞における肝関連マーカー $(C Y P 3 A 4, C Y P 2 C 9$, $C Y P 2 C 19, \alpha A T)$ の遺伝子発現量を real-time RTPCR 法により確認したところ，いずれの発現量も 肝分化後の HBC の方が有意に高く, PHH とほぼ 同程度であった [Fig. 3(G)]．以上のことから， laminin 111 上で維持・複製した HBC は肝細胞へ の分化能を有していることが確認できた.

\section{5. おわりに}

本研究では，遺伝子導入技術と三次元培養技術を 用いることにより，ヒト ES/iPS 細胞から PHH に 近い機能を有する肝細胞を高効率に作製することに

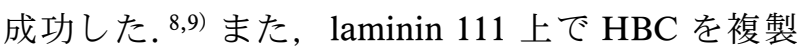
可能であることも明らかとし，ヒト ES/iPS 細胞由 来肝細胞を大量供給するための基盤技術の構築に成 功した. ${ }^{10)}$ 本稿では割愛したが，われわれは三次元 共培養技術を用いてヒト ES/iPS 細胞由来肝細胞の 更なる成熟化にも成功している. ${ }^{11)}$ さらに，われわ れが作製しているヒト ES/iPS 細胞由来肝細胞が個 別化医療, ${ }^{12)}$ 再生医療, ${ }^{13)}$ ヒ卜発生学 ${ }^{14,15)}$ にも応用 できる可能性を実証している，本研究がヒト ES/ iPS 細胞由来肝細胞の医療応用に大いに役立つこと を期待する.

謝辞本稿で紹介した研究は，国立大学法人大 阪大学大学院薬学研究科分子生物学分野, 医薬基
盤・健康・栄養研究所肝細胞分化誘導プロジェク 卜，同研究所幹細胞制御プロジェクトにて行われた ものであり，多大なご支援・ご協力を頂いた水口裕 之教授を始めとする関係者の皆様に深謝いたします。

利益相反高山和雄 (特許 (PCT / JP2014/ 60228）の実施補償金をレジエンス株式会社から受 領).

\section{REFERENCES}

1) MacDonald J. S., Robertson R. T., Toxicol. Sci., 110, 40-46 (2009).

2) Agarwal S., Holton K. L., Lanza R., Stem Cells, 26, 1117-1127 (2008).

3) Koizumi N., Mizuguchi H., Utoguchi N., Watanabe Y., Hayakawa T., J. Gene Med., 5, 267-276 (2003) .

4) Tashiro K., Kawabata K., Inamura M., Takayama K., Furukawa N., Sakurai F., Katayama K., Hayakawa T., Furue M. K., Mizuguchi H., Cell. Reprogram., 12, 501-507 (2010) .

5) Inamura M., Kawabata K., Takayama K., Tashiro K., Sakurai F., Katayama K., Toyoda M., Akutsu H., Miyagawa Y., Okita H., Kiyokawa N., Umezawa A., Hayakawa T., Furue M. K., Mizuguchi H., Mol. Ther., 19, 400-407 (2011).

6) Takayama K., Inamura M., Kawabata K., Tashiro K., Katayama K., Sakurai F., Hayakawa T., Furue M. K., Mizuguchi H., PLoS One, 6, e21780 (2011).

7) Takayama K., Inamura M., Kawabata K., Katayama K., Higuchi M., Tashiro K., Nonaka A., Sakurai F., Hayakawa T., Furue M. K., Mizuguchi H., Mol. Ther., 20, 127-137 (2012).

8) Takayama K., Inamura M., Kawabata K., Sugawara M., Kikuchi K., Higuchi M., Nagamoto Y., Watanabe H., Tashiro K., Sakurai F., Hayakawa T., Furue M. K., Mizuguchi H., J. Hepatol., 57, 628-636 (2012).

9) Takayama K., Kawabata K., Nagamoto Y., Kishimoto K., Tashiro K., Sakurai F., Tachibana M., Kanda K., Hayakawa T., Furue M. K., Mizuguchi H., Biomaterials, 34, 
1781-1789 (2013).

10) Takayama K., Nagamoto Y., Mimura N., Tashiro K., Sakurai F., Tachibana M., Hayakawa T., Kawabata K., Mizuguchi H., Stem Cell Reports, 1, 322-335 (2013).

11) Nagamoto Y., Tashiro K., Takayama K., Ohashi K., Kawabata K., Sakurai F., Tachibana M., Hayakawa T., Furue M. K., Mizuguchi H., Biomaterials, 33, 4526-4534 (2012) .

12) Takayama K., Morisaki Y., Kuno S., Nagamoto Y., Harada K., Furukawa N., Ohtaka M., Nishimura K., Imagawa K., Sakurai F., Tachibana M., Sumazaki R., Noguchi E., Nakanishi M., Hirata K., Kawabata K., Mizuguchi H., Proc. Natl. Acad. Sci. USA, 111, 16772-16777 (2014).
13) Nagamoto Y., Takayama K., Tashiro K., Tateno C., Sakurai F., Tachibana M., Kawabata K., Ikeda K., Tanaka Y., Mizuguchi H., Cell Transplant., 24, 11271138 (2015).

14) Takayama K., Kawabata K., Nagamoto Y., Inamura M., Ohashi K., Okuno H., Yamaguchi T., Tashiro K., Sakurai F., Hayakawa T., Okano T., Furue M. K., Mizuguchi H., Development, 141, 91-100 (2014) .

15) Watanabe H., Takayama K., Inamura M., Tachibana M., Mimura N., Katayama K., Tashiro K., Nagamoto Y., Sakurai F., Kawabata K., Furue M. K., Mizuguchi H., PLoS One, 9, e90791 (2014). 